\title{
Coping With Global Warming
}

\author{
Jan-Erik Lane ${ }^{1}$ \\ ${ }^{1}$ Jan-Erik Lane iis a fellow with Public Policy Institute in Belgrade.. \\ Correspondence: Jan-Erik Lane, an independent scholar who has been full professor at 3 universities and visiting \\ professor at many more.
}

Received: May 26, 2015

Accepted: June 10, 2015

Available online: July 8, 2015

doi:10.11114/aef.v2i3.937

URL: http://dx.doi.org/10.11114/aef.v2i3.937

\begin{abstract}
The process of globalization that has framed developments in the societies on Planet Earth the last decades will be supplanted by the climate change process, which no country can evade. It amounts to a set of giant forces shaping the environment, the economies and the politics of the world. It is somehow believed that the process of change can be controlled by halting the increase in greenhouse gases so that average global temperature would only augment by 2 degrees. This is a dire illusion, fed by the promises of many governments to do something about the energy emissions in the future! Global warming is now, driven by the most powerful forces, namely the life style of mankind, resulting in an ever larger decline in environmental capital. There is much talk about creating economic development that is carbon neutral, but the global truth is that emission of greenhouse gases just keeps going up. China has promised to halt emission growth by 2030 - too late! Global coordination fails completely.
\end{abstract}

Keywords: global warming as social change, resilience - wait and see, adaptation, global tragedy of the commons, the confusion of total and per capita emissions, the Juggernaut links between GDP, energy and emissions, environmental refugees, ecological damages, life style.

\section{Introduction}

The manifestations of the global warming process show up in daily evidence about sea level rise, warming oceans, the melting of ice, the decrease of lakes and rivers, draughts and desertification, etc. Together with other trends towards the overexploitation of the environment, Planet Earth is heading towards en ecological crisis, if not catastrophe. No one can tell exactly how much average global temperature will rise, but given that the emissions and the overexploitation of nature continues, it cannot be excluded that global temperature will rise more than 6 degrees, which would spell disaster for mankind.

Yet, little is done as the process of global warming gathers momentum. On the one hand, it is business as usual: energy consumption goes up year in and year out as more and more people reach higher levels of living standards, the turn to shale oil and gas leads to lower energy prices for the foreseeable future and the employment of renewable resources or carbon neutral technology is not strong enough to offset the dependency upon fossil fuels and the emissions there-off.

On the other hand, global ecology policy-making falters. Domestically, many countries have too weak states to control environmental resources, which put incredible pressure upon wild-life and ocean organisms. Internationally, a series of global meetings as well as a well-funded UN programe for environmental protection has failed to halt the "global tragedy of the commons", as governments make promises but delivers little or simply reneges. What is needed is the combination of domestic and international policies to stop global warming and protect environmental resources of all kinds. But it will not come about, as the governments of the world choose resilience - wait and see - ahead of precaution - take action now. The human race will have to adapt to the process of global warming, as islanders and costal inhabitants have already started to do.

\section{The Forces behind Global Warming}

Global warming, starting to have real life effects some 10 years after economist Stern warned about the largest externality in human history, has been related to 3 major social forces: population growth, capitalism as economic system and life-style. I will argue that it is the latter that fuels global warming the most through the link between energy, emissions and climate change. 


\section{a) Population increase}

Human beings contribute to the $\mathrm{CO} 2$ emissions through their lungs all the time. This implies that a considerable growth in human population results in more $\mathrm{CO} 2$ emissions. The enormous increase in $\mathrm{CO} 2$ emissions during the recent 3 decades has been fuelled party by mean of strong population growth. As mankind is predicted to keep growing until some 9 billion inhabitants, $\mathrm{CO} 2$ emissions must go up, all other things equal. But the contribution of human breathing is not really that large in terms of percentage, or less than 10 per cent. Figure 1 show the composition and origins of the greenhouse gases.
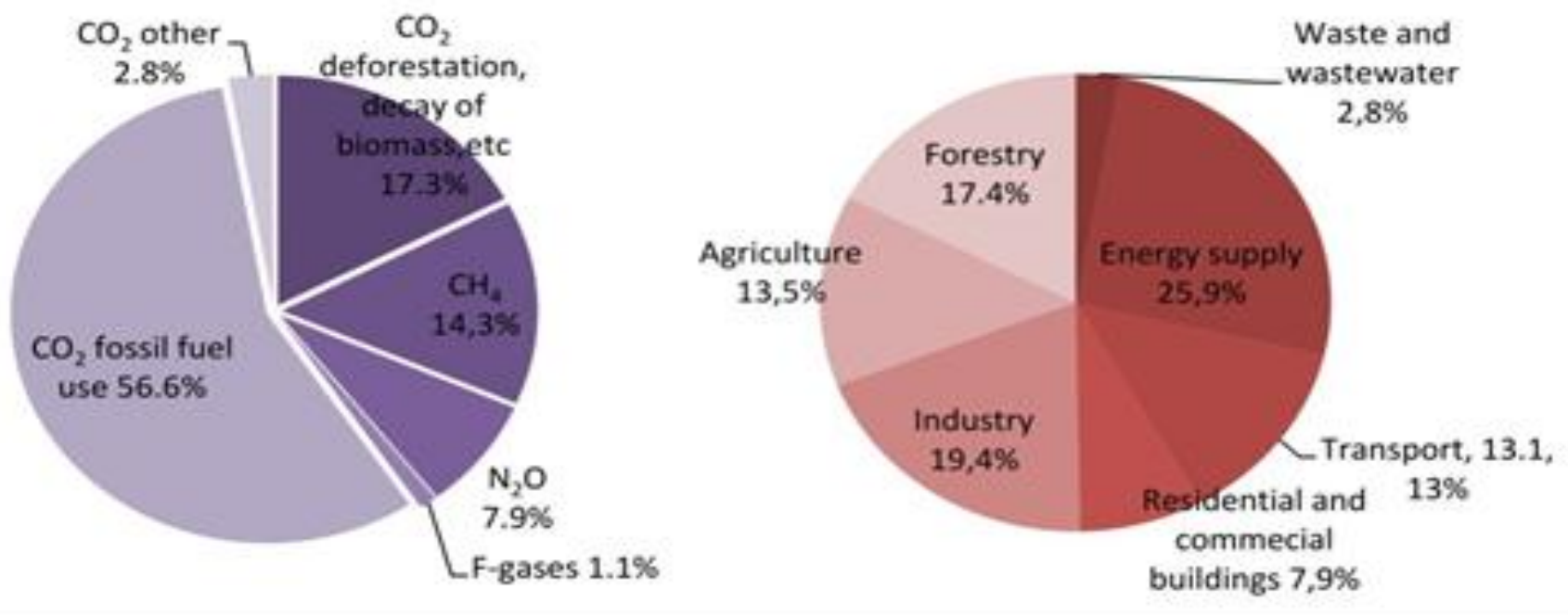

Figure 1. Composition of Greenhouse Gases

A Mathusian explanation of global warming is not sufficient. Only some 10 per cent of global CO2 emissions come from human beings. Other factors must be taken into account. Population growth will augment carbon emissions, but the indirect effect over the economy will be much larger. The Malthus focus upon a major difference in growth rates between resources and people does not capture the essence of the climate change problematic, as resources may still keep on being exploited while the atmosphere is poisoned.

\section{b) Capitalism}

One finds the theory of capitalism as the cause of the environmental disasters not only in old Marxist thought but also in the anti-globalisation literature (Klein, 2014). The difficulty is not to show that the prevailing economic system of the global economy - the market economy - causes lots of ecological costs, but to provide a tenable argument that there is a viable alternative to the market economy.

John Bellamy Foster and associates have launched an attempt to renew the Marxist analyses of global capitalism, originating with Hilferding as well as Baron and Sweezy. In terms of the approach here, the neo-Marxist analysis (Foster et al, 2011; Foster et al, 2012) looks very much as the global market as a constant sum game.

Firstly, the gains from the global market economy are more and more appropriated by the financial system and its institutions, focusing upon quick profits from managing gigantic transactions in paper assets. Thus, the centre in the neo-Marxist approach is no longer the accumulation of surplus value in the real economy, the capitalist exploiting the worker. Instead, the current crisis in the EU and the US has to do with a crisis of monopoly-finance capitalism, and the tendency toward secular stagnation in mature capitalist economies. This reduces investment opportunities in the real economy, driving capital to seek other sources of profit through the financial economy. The construction of a "casino" economy built on increasingly complex financial mechanisms is collapsing under its own contradictions. The monopolization of the economy - when a handful of large firms dominate one or several industries - leads to an over-abundance of capital and too few profitable investment opportunities Absent powerful stimuli to investment, modern capitalist economies have become increasingly dependent on the financial sector to realize profits. And while the financial sector may offer a temporary antidote to stagnation, it is a solution that cannot last long.

Secondly, in the neo-Marxist analysis ecological concerns are added to the picture of global competition. This reinterpretation of Marx on ecology introduced the concept of "metabolic rift" and was widely influential in theorizing the relationship between the global environmental crisis and the crisis in the capitalist economy, while stressing the imperative for a sustainable, socialist alternative. Foster stated:

Developing an environmental sociology as an integral part of sociology as a whole thus requires that we reach back into 
past theories in order to develop the intellectual means for a thoroughgoing analysis of the present. For environmental sociology the crucial issue today is to abandon the "strong constructionism" of most contemporary sociological theory, which tends to view the environment as simply a product of human beings, and to move toward a more "cautious constructionism" that recognizes that there is a complex metabolic relation between human beings and.... (Foster, 1999, AJS Volume 105 Number 2: 366-405).

The neo-Marxist recognition of the relevance of ecological concerns contrasts much with the policies of Communist regimes during the $20^{\text {th }}$ century as well as with China's position on global warming today. Yet, it is a most timely acknowledgement that established measures on welfare like yearly rates of economic growth are defective and should be complemented by for instance ecology footprint scores on pollution of various kinds, including emissions of $\mathrm{CO} 2$ equivalents.

The neo-Marxist analysis of global capitalism is strongly emphasizing its zero-sum aspects, economic growth being accomplished at huge environmental costs and what is left to be divided ending up with the people in the financial system to the exclusion of the poor, the unemployment and the increasingly fragile middle classes. One may point to interesting empirical evidence for this zero-sum approach in the new index of economic welfare, taking into account the environmental run down of the globe and in combining economic growth indices with environmental sustainability indices, as well as in the clear evidence of rising inequalities the world over (Stiglitz, 2012).

Yet, could any other type of economic system do better? The only kind of economy that delivers affluence is the market economy. It may not be perfect but it produces goods and services, although not social justice. If capitalism is the market economy, then Planet Earth cannot do without capitalism. It may need profound reforms, if at all feasible, but other mechanisms of allocation such as planning or command work even worse, also from the ecological point of view. China is actually the largest polluter today with its market socialism type of economy.

The debate about the pros and cons of "capitalism" has been raging since the publication of the Wealth of Nations. Shortly, one may make a few distinctions that are helpful in the contemporary discussion about capitalism and the growing ecological deficit for Planet Earth. "Capitalism" is a word with several and different meanings, to be found in the analyses of Say, Weber, Sombart, Schumpeter and Williamson:

1) Capitalism as greed (Weber):In all forms of economic life, many people are driven by excessive greed at times. Weber stated that if capitalism equals greed, then we have to examine agrarian, state, feudal, mercantile and industrial capitalism. $20^{\text {th }}$ century scholars would add the capitalism of banks and financial institutions.

2) Capitalism as rationality (Weber): As is well-known, Weber argued that there was a specific form of Western rational capitalism: the large scale industries with free labour and bourses. It has no doubt spread around the globe.

3) Capitalism as innovation (Schumpeter): The central figure in modern capitalism is the entrepreneur who transforms innovations into mass production and employment. Modern capitalism differs from all other forms of economic life in that it means constant social change: "creative destruction".

4) Capitalism as exploitation (Marx):greed or excessive profit hunger may of course result in brutal exploitation, as when in early modern capitalism wages were set at subsistence level. But Marx underestimated the bargaining power of workers against capitalists, as already Tocqueville pointed out in his Democracy in America.

5) Capitalism as imperialism (Lenin): $20^{\text {th }}$ century Marxism devoted much analysis to the incorporation of the Third World into the global economy, where Third world countries became the periphery of the core capitalist countries.

6) Capitalism as evolution (Sombart): if one examines different capitalist economic systems, then one may discover a pattern, an evolution from early to high to later stages of capitalism, from agricultural to mercantile to industrial capitalism. One may ask: What is next? Green capitalism?

7) Capitalism as institutional set-up (Williamson): instead of focusing upon capitalist behaviour, one may define "capitalism" as a set of rules for the market economy: private property, free labour contracts, Limited Liability Company, bourses, equality under the law, etc.

When capitalism is singled out as the cause of environmental disasters and the decline of ecological capital (nobody owns it!), such talk runs with an opaqueness:

a) What capitalism? Legal or illegal?

b) Is there any realist alternative to institutionalised capitalism?

c) How can environmental protection become a part of the workings of the "invisible hand"? 


\section{d) Life Style}

It was once stated that when the population masses in China and India started to adopt the American life style, then Planet Earth would run into problems. This theme was explored in the Limits to Growth literature. However, this literature underlined the scarcity of all resources on the planet, but climate change refers basically to one potentially catastrophic change: the composition of the atmosphere.

The emission of greenhouse gases has increased enormously in a short period when affluence has spread around the globe: all the cars, the huge sea and air traffic, the building of cement structures everywhere, urbanization, communications lines, air-conditioning, meat production, cows and pigs, conspicuous consumption, private jets and yachts, one person - several houses or apartments, etc. The middle classes are more numerous in China and India today than in Germany. And the super-rich number the same as in the US. This life style is based upon one thing, namely a massive increase in energy consumption, which is necessary to produce all these goods and services including food, i.e. agriculture and fishing industry.

\section{Juggernaut Links}

Men and women must work, eat and sleep. Thus, they search for the economic activities that help procure basic necessities for them. The global market economy engulfs all countries in the world, as self-sufficiency only is self-defeating. During the post-war period, total production has risen enormously, as global trade has increased year in and year out. Economic development and growth has lifted millions into affluence or even super-affluence. But it has come with a specific cost besides general environmental degradation, namely the emission of greenhouse gases (Figure 1).

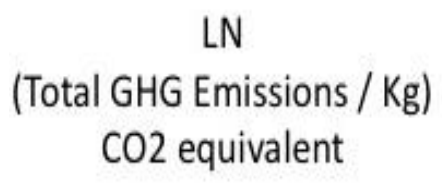

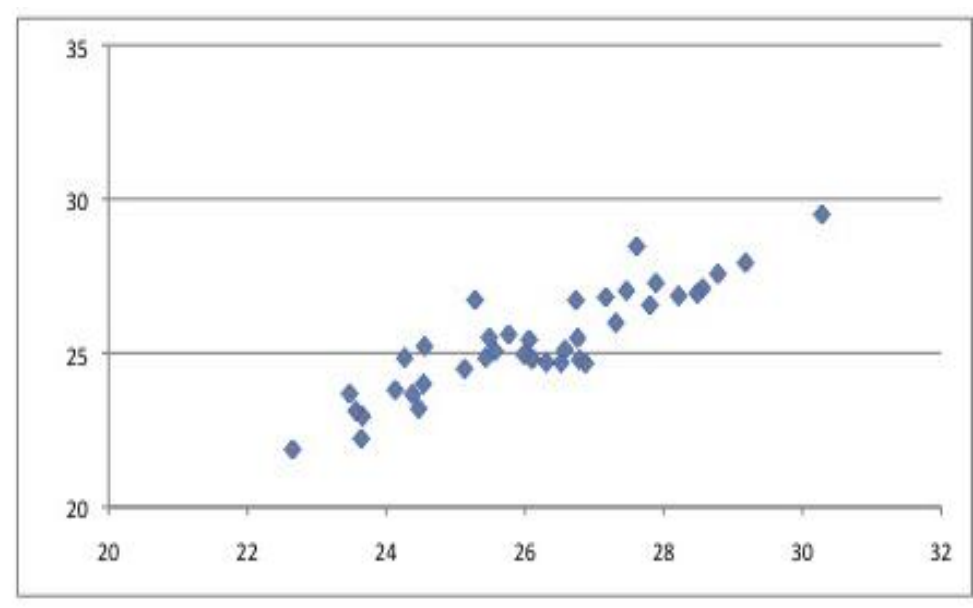

LN ( GDP / USD) (constant value 2005)

Figure 1. GDP - Emissions 2012.

Sources: a) World Bank national accounts data, b) OECD National Accounts Data Files, c) United Nations Framework on Climate Change GHG inventory submissions. Equation: $\mathrm{y}=0.85 \mathrm{x}, \mathrm{R} 2=0.804$.

The bigger total output is in a country, the more emissions it emits! This implies that the nations with the largest GDP must take the brunt of the reductions in emissions, if this ever would come about.

The link between GDP and emissions is energy consumption. All forms of enegy are used in the production of goods and services. And energy consumption goes up all the time - see Figure 2 


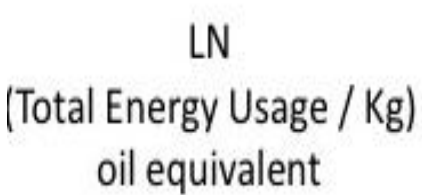

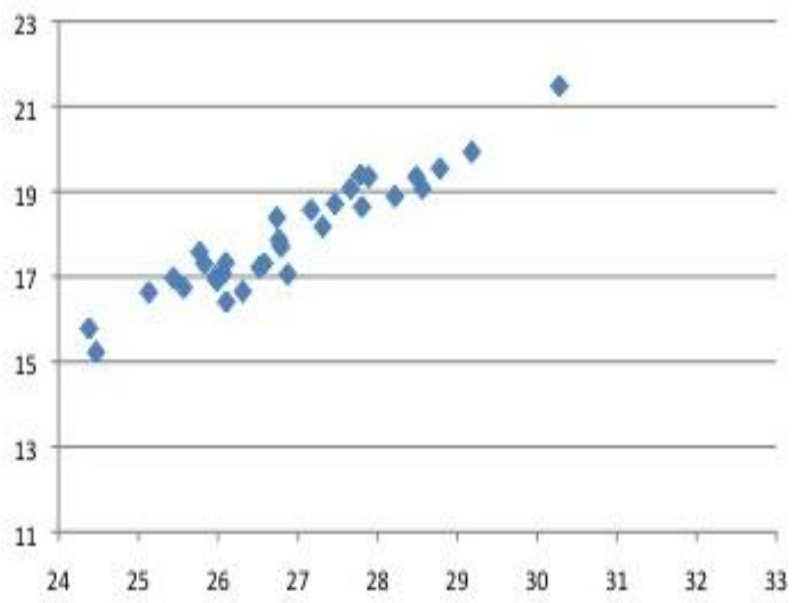

LN ( GDP / USD) (constant value 2005)

Figure 2.GDP - Energy Usage 2012.

Sources: a) World Bank national accounts data, b) OECD National Accounts Data Files, c) International Energy Agency Statistics. Equation: $\mathrm{y}=0.88 \mathrm{x}, \mathrm{R} 2=0.908$

The US agency Energy Information Administration (EIA) not only documents the especially strong increase in energy consumption since 1980 when the process of globalisation picks up speed. The EIA also predicts future developments towards even much higher levels of energy consumption. From what sources of energy? - one may ask.

One can only fear the consequences for emissions growth of such dramatic increases in energy consumption the next decade, if they are at all realistic. Figure 3 depicts the link between energy consumption and emissions.

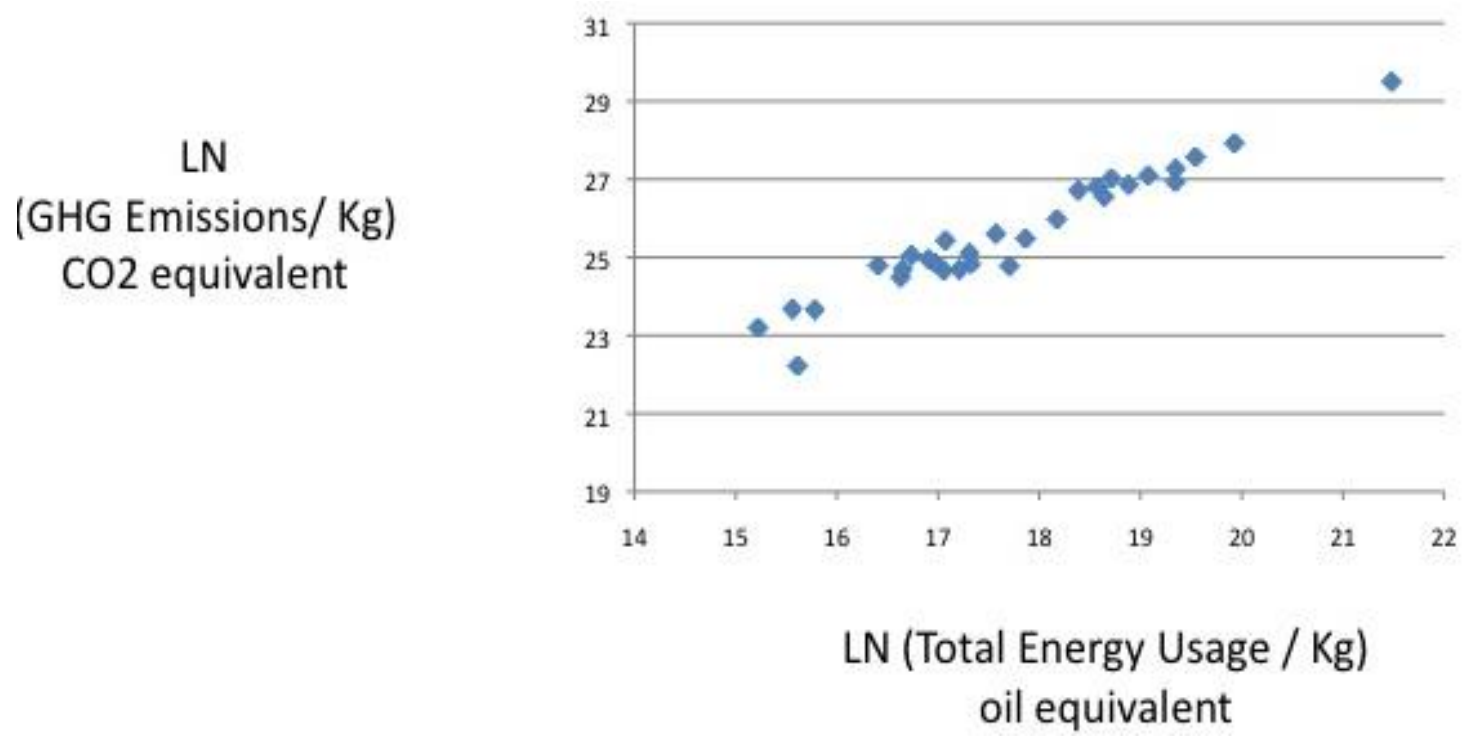

Figure 3. Energy - Emissions 2012.

Sources: a) International Energy Agency Statistics, b) United Nations Framework on Climate Change GHG inventory submissions. Equation: $\mathrm{y}=1.05 \mathrm{x}, \mathrm{R} 2=0.941$

What appears in Figure 3 is the global level link between energy and emissions. It does in no way exclude that energy consumption or production can be carbon neutral. This has been demonstrated in several micro level projects. The problem is that traditional economic development tends to be highly energy consuming that in turn still is pollution, in general or an average projects.

Summing Up: The basic argument here is that affluence is the major determinant of global warming, i.e. life style. Let us look shortly at water consumption to see what matters most: population size or total GDP. 


\section{WATER: A Note}

The depletion of fresh water is starting to be felt seriously at many places in the world. Rivers and lakes are drying up and water tables dwindle. What follow are draught and desertification and later on poverty and higher prices. The water problematic is partially related to climate change, as hotter climate decimates fresh water resources and raises salt water levels. But the water supply problem also has its own background in huge urban expansion pollution and irrigation.

In the data on fresh water resources, one makes a distinction between water withdrawals on the one hand and water consumption on the other hand. The former concept is much broader than the latter, as it includes water that returns to the soil, whereas water consumption is final, al least normally. Now, what is a determinant of the variation in country usage of fresh water totally? Population or GDP? Figure 4 relates water withdrawal to the GDP of a country, suggesting that life style matters considerably.

Total GDP vs. Total freshwater withdrawal in 2013

\section{LN \\ (Freshwater withdrawal / cubic metres)}

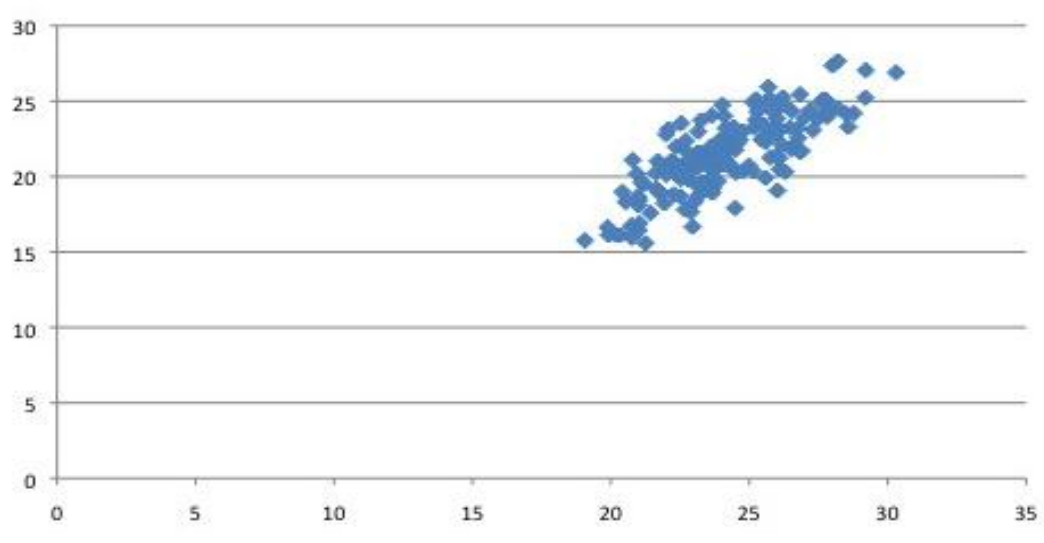

LN (GDP in constant value 2005 USD)

Figure 4. Country: Total water withdrawal and GDP.

Sources: GDP: World Bank / OECD, Water withdrawal: FAO, Aquastat Database. Equation: $y=0,88 x$, R2=0,611

Looking at the close connection in Figure 4, one could argue that the link between water withdrawal and country affluence also holds at the micro level, per capita withdrawal being higher in countries with higher GDP. Figure 5 rejects this hypothesis.

GDP per capita vs. Freshwater withdrawal per capita in 2013

LN

(Freshwater withdrawal / capita, cubic metres)

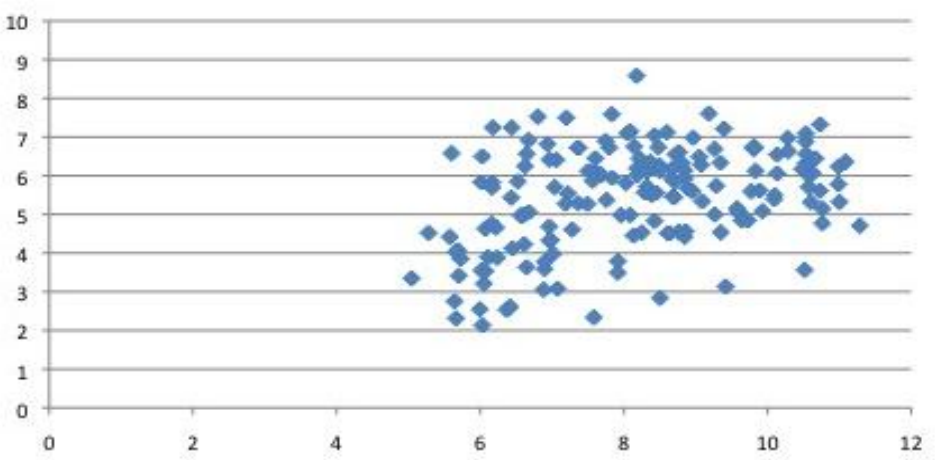

LN (GDP per capita in constant value 2005 USD)

Figure 5. Per capita: Water withdrawal and GDP.

Sources: GDP: World Bank / OECD, Water withdrawal: FAO, Aquastat Database. Equation: $y=0,31 x, R 2=0,139$

One observes that water withdrawal per capita has other determinants than per capita affluence, the need for irrigation 
being a major factor like also high temperatures on average. Interestingly, Figure 6 shows that the size of the population has less impact than the size of the GDP!

\section{Population vs. Freshwater withdrawal in 2013}

\section{$\mathrm{LN}$ \\ (Freshwater withdrawal / cubic metres)}

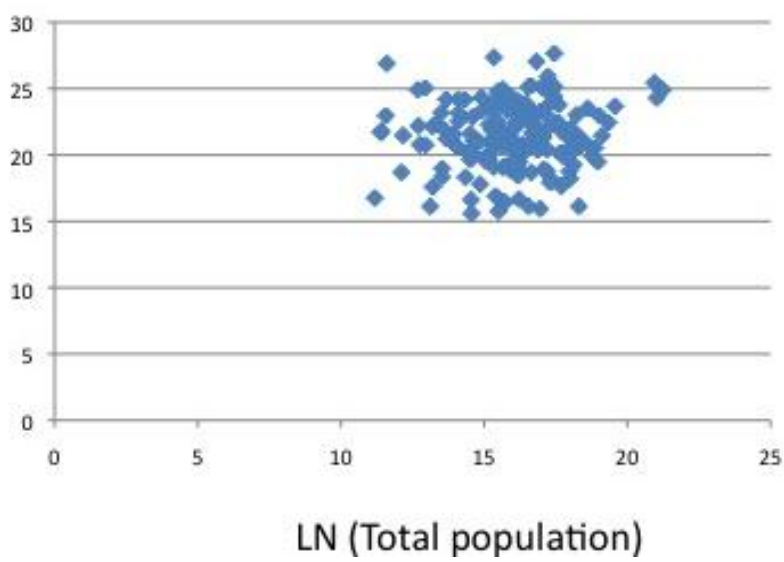

Figure 6. Country: Water withdrawal and population.

00871 Sources: Population: 1) United Nations Population Division. World Population Prospects, (2) United Nations Statistical Division. Population and Vital Statistics Report (various years), (3) Census reports and other statistical publications from national statistical offices, (4) Eurostat: Demographic Statistics, (5) Secretariat of the Pacific Community: Statistics and Demography Programme, and (6) U.S. Census Bureau: International Database. Water withdrawal: FAO, Aquastat Database, Equation: $\quad \mathrm{y}=0.13 \mathrm{x}, \mathrm{R} 2=0$.

Thus, one may conclude that countries with large populations do not withdraw more water than countries with small populations, generally speaking. It is the GDP that matters more than population size. No linear connection here between population and water withdrawal.

\section{Coordination Failure}

The climate change problematic is severely aggravated by profound coordination difficulties, as governments simply cannot cooperate easily to cut back emissions. Governments have one major priority, namely economic development or economic growth, and when this goal collides with costs for the environment and climate change, then governments renege or postpone action. Or they begin arguing about who is to reduce the most. Carbon neutral technology is sometimes available for investments in new projects, but it is only employed in a piecemeal fashion. Some countries boast that they are the leaders of carbon neutral economic development, but at the same time they have the highest emissions per capita in the world: Qatar, Kuwait, UAE and Singapore to some extent!

Two difficulties make for coordination failure:

\section{(1) Free riding: Warming's insight 1911}

The pollution of the atmosphere with greenhouse gases is like much environmental degradation a prisoners' dilemma game due to open access, creating the externality problematic in Stern's vocabulary (Stern, 2006). When a resources lies in open access, then it will not be allocated in a Pareto-optimal fashion, not even in the long-run. Instead, the players involved in harvesting the resources will capture as much as they can individually and myopically (Nash equilibrium). There are two situations, already discovered by Danish economist J. Warming, anticipating the tragedy of the commons (Scott, Gordon, Hardin):

1) If the use of the open access resources involves costs, then the resources will be exploited until average cost $=$ average value, depleting the economic rent completely;

2) If the use of the open access resource is free without any charge, then its use will be driven to extinction.

At first, the emission of greenhouse gases could be done freely, meaning that nobody cared. Secondly, small groups of people concerned by the local effects of climate change began to complain - environmental refugees. Now, several governments have started to realize the dangers as the pollution costs mount, but how can they handle the transaction costs involved in managing a gigantic PD game with 200 players?

The costs of global warming differ locally, but they are an obvious concern for all governments. Now, how are the costs of reducing the emission of greenhouse gases to be divided onto the various governments $=\mathrm{N}$ ? If this requires accepting 
lower economic growth rates in a few countries, should the costs be shared by all somehow? Suppose the total cost of reducing emissions by 50 per cent is $\mathrm{C}$. A single small country would argue that it could not take its share $\mathrm{C} / \mathrm{N}$, because there would be no real difference if it was left out of the global agreement, i.e. $\mathrm{C} / \mathrm{N}-1$. Or a huge country could argue that it would not wish to take on a major part of the cost, because it is only one of many polluting countries and whatever sacrifice it makes will be shared with the others, i.e. 1/N.

\section{(2) Polish Diet (transaction costs): Wicksell's major mistake 1896}

Since the global coordination meetings on climate change employ unanimity as decision method, the transaction costs sky-rocket. The outcome is predictable: delays, promises not fulfilled, postponements, etc. Then we must add the confusion of total and per capita emissions.

Let us first draw a picture of the total emissions by means of a list of the ones with most emissions, measured in millions of metric tons (Table 1).

Table 1. Countries with most emissions of greenhouse gases (mt) 2010

\begin{tabular}{|c|c|c|}
\hline $\begin{array}{l}\text { Country } \\
\text { China }\end{array}$ & $\begin{array}{l}\text { Greenhouse gases } \\
9,679.30\end{array}$ & $\begin{array}{l}\text { In per cent } \\
22.7\end{array}$ \\
\hline USA & $6,668.79$ & 15.6 \\
\hline $\mathrm{EU}-28$ members & $4,663.41$ & 10,9 \\
\hline India & $2,432.18$ & 5.7 \\
\hline Russia & $2,291.57$ & 5.4 \\
\hline Japan & $1,257.10$ & 2.9 \\
\hline Brazil & $1,104.64$ & 2.6 \\
\hline Indonesia & 814.71 & 1.9 \\
\hline Canada & 710.72 & 1.7 \\
\hline Iran & 698.38 & 1.6 \\
\hline Mexico & 681.87 & 1.6 \\
\hline South Korea & 661.69 & 1.6 \\
\hline Australia & 560.64 & 1.3 \\
\hline Saudi Arabia & 510.14 & 1.3 \\
\hline South Africa & 458.29 & 1.1 \\
\hline Ukraine & 380.89 & 0.9 \\
\hline Argentina & 363.79 & 0.9 \\
\hline Nigeria & 320.04 & 0.8 \\
\hline Pakistan & 304.85 & 0.7 \\
\hline Kazakhstan & 300.83 & 0.7 \\
\hline Venezuela & 284.99 & 0.7 \\
\hline Malaysia & 282.60 & 0.7 \\
\hline Taiwan & 278.34 & 0.7 \\
\hline Uzbekistan & 215.36 & 0.5 \\
\hline Total & & $83 \%$ \\
\hline
\end{tabular}

Source:http://en.wikipedia.org/wiki/List_of_countries_by_greenhouse-gas_emissions

The structure of total emissions of greenhouse gases for global policy-making entails that what a mere 20 countries, responsible for 80 per cent of them, do will decide the outcomes. Were they to reduce their emissions by 5 per cent a year, it would have a tremendous impact upon the risks of climate change. Total emissions are a function of huge economy, sizeable affluence and Soviet legacy. But instead the UN orchestrates mega reunions with all states of the 
world and confuses total emissions with emissions per capita.

Table 2 shows that the list of countries with very high $\mathrm{CO} 2$ emissions per person is very different from Table 1. It includes a number of tiny countries that are hardly relevant for the global policy aim to reduce emissions significantly, sooner than later.

Table 2. Countries: CO2 Emissions per Capita

\begin{tabular}{llr}
\hline 1 & Qatar & 49.05 \\
2 & Trinidad and Tobago & 37.39 \\
3 & Kuwait & 30.11 \\
4 & Brunei Darussalam & 27.54 \\
5 & United Arab Emirates & 24.98 \\
6 & Aruba & 21.68 \\
7 & Luxembourg & 21.49 \\
8 & Bahrain & 21.36 \\
9 & Australia & 18.57 \\
10 & United States & 17.96 \\
11 & Oman & 17.35 \\
12 & Saudi Arabia & 16.57 \\
13 & Canada & 16.33 \\
14 & Kazakhstan & 15.12 \\
15 & Faeroe Islands & 14.56 \\
16 & Estonia & 13.64 \\
17 & New Caledonia & 12.91 \\
18 & Russian Federation & 12.04 \\
19 & Czech Republic & 11.22 \\
20 & Finland & 10.64 \\
21 & Netherlands & 10.57 \\
22 & Palau & 10.51 \\
23 & Norway & 10.48 \\
\hline
\end{tabular}

Source:http://www.conferenceboard.ca/hcp/details/environment/greenhouse-gas-emissions.aspx

It may seem fair that all countries contribute to reduce greenhouse gases like $\mathrm{CO} 2$ emissions, but it is not efficient to focus upon emissions per capita. Which countries should then make the largest sacrifices? Those with huge total emissions or those with largest par capita emissions?The richest countries or all countries proportionately to some $\mathrm{X}$ factor?

World famous economist, Sweden's K. Wicksell, argued that the golden decision rule for a group like the states of the world is consensus or unanimity, because it leads to Pareto optimality in decision-making. This became the foundation of the public choice school with Buchanan and Tullock(1962). However, this theory is flawed due to transaction costs. Unanimity in large groups leads to endless discussion, voting and stale-mate. The governments of the world have tried the Wicksell policy-making style for decades, but with no outcome except delay. The Paris meeting will only result in declarations and promises, no real implementation. China has promised to act 2030 - it is too late. For international meetings and organisations hold that only quantitative voting on the basis of qualified majority delivers results.

\section{Conclusion}

The global response to climate change is going to be: resilience - wait and see, act afterwards. Total emissions of greenhouse gases may go down somewhat due to slower economic growth as well as many new ways of employing renewable sources of energy. But the basic fact will not change, viz. that the emissions of 50 trillion kilos of greenhouse gases into the atmosphere year in and year out will change global climate in a very dangerous manner for mankind and other living species.

Resilience is rational when one does not know the real situation and cannot predict the outcomes of alternative policies. However, resilience may end up in the worst possible scenario: steady increase in global temperature: air, land and sea. First, we will have the environmental refugees from the islands, then the population migrations from flooded coats, afterwards the draughts and desertification, the elimination of the rest of the rain forests, and finally the water and food shortages.

Climate change is evolutionary, and as such unstoppable. Coping with climate change entails resilience, or doing the best you can ex post. It will lead to people migration and the resettlement of millions. The oceans will be transformed hotter, more acid, less life. People will go to new places where it is cooler, abandoning popular sites. There will be 
shortages: fresh water, food and energy. But men and women can cope with much environmental change including damages, although costly indeed!

The G7 has recently proclaimed its "ambitious" goal to reduce the emissions of greenhouse gases by $50 \%$ by 2050 , at the same time as the information arrives that the first half of 2015 is the warmest ever, The G7 policy-making is typical of "wait and see" - no plan, no commitments in the short-run, just pushing the problem into a distant future. People will thus have to learn hos to adapt when the changes arrive, hoping that mankind will be resilient in this major coping process. 2050 will be too late as policy target.

\section{References}

Buchanan, J. M., \& Tullock, G. (1962). The Calculus of Consent. Ann Arbor: University of Michigan Press. Finanzen.

Klein, N. (2014). This Changes Everything: Capitalism versus the Climate. New York: Simon and Schuster.

Mueller, D. C. (2003). Public Choice III, Cambridge: Cambridge University Press. http://dx.doi.org/10.1017/CBO9780511813771

Musgrave, R. A. (1983), Public finance, now and then, Finanzarchiv, N. F. Bd. 41, Heft 1, 1-13.

Samuelson, P. A., Musgrave, R. A., \& Sandelin, B. (eds) (1988). Wicksell: VademecumzueinemfrühenKlassiker der ökonomischenWissenschaft, Düsseldorf: Wirtschaft und.

Schumpeter, J. A. (1989). Essays: On Entrepreneurs, Innovations, Business Cycles, and the Evolution of Capitalism. Transaction Books.

Sombart, W. (1991). Der Moderne Kapitalismus I-IV. DTV Deutscher Taschenbuch

Stern, N. (2006). Stern Review on The Economics of Climate Change (pre-publication edition). Executive Summary, HM Treasury, London.

Wagner, R. E. (1988). The calculus of consent: a Wicksellian retrospective, Public Choice, 56, 153-66. http://dx.doi.org/10.1007/BF00115754

Warming, J. (1911). Om grundrente af fiskegrunde[On Rent of Fishing Grounds],Nationalökonomisk tidsskrift, 499-505.

Weber, M. (1978). Economy and Society. Berkeley: University of California Press.

Wicksell, K. (1958). Finanztheoretische Untersuchungen, Jena: Gustav Fischer (English trans.: A new principle of just taxation, in R. Musgrave and A.T. Peacock (eds), Classics in the Theory of Public Finance, New York: St. Martin's Press, $72-118$.

Williamson, O. (1985). The Institutions of Capitalism. New York: Free Press.

\section{(cc) BY}

This work is licensed under a Creative Commons Attribution 3.0 License. 